Article

\title{
Preparation and Identification of Antioxidative Peptides from Pacific Herring (Clupea pallasii) Protein
}

\author{
Xueqin Wang ${ }^{1,2}$, Huahua Yu ${ }^{1,2}$, Ronge Xing ${ }^{1,2}$, Song Liu ${ }^{1,2}$, Xiaolin Chen ${ }^{1,2} \mathbb{D}$ and \\ Pengcheng Li ${ }^{1,2, *}$
}

1 Key Laboratory of Experimental Marine Biology, Center for Ocean Mega-Science, Institute of Oceanology, Chinese Academy of Sciences, No 7, Nanhai Road, Qingdao 266071, China; xueqinwang@qdio.ac.cn (X.W.); yuhuahua@qdio.ac.cn (H.Y.); xingronge@qdio.ac.cn (R.X.); sliu@qdio.ac.cn (S.L.); chenxl@qdio.ac.cn (X.C.)

2 Laboratory for Marine Drugs and Bioproducts of Qingdao National Laboratory for Marine Science and Technology, No 1, Wenhai Road, Qingdao 266237, China

* Correspondence: pcli@qdio.ac.cn; Tel.: +86-532-8289-8707

Academic Editors: María Pilar Almajano and Michael H. Gordon

Received: 12 April 2019; Accepted: 18 May 2019; Published: 21 May 2019

\begin{abstract}
The aim of this study was to isolate and purify antioxidative peptides from Pacific herring (Clupea pallasii) protein. Five enzymes (pepsin, trypsin, papain, flavourzyme, and neutrase) were used for protein hydrolysis, and Pacific herring protein hydrolysates (PHPH) were separated by ultrafiltration. The fraction with the molecular weight below $3500 \mathrm{Da}$ exhibited the highest in vitro antioxidant activities and cellular antioxidant activity. The PHPH was isolated and purified by consecutive chromatographic methods including gel filtration chromatography and reverse high-performance liquid chromatography (RP-HPLC). The purified antioxidant peptides were identified as Leu-His-Asp-Glu-Leu-Thr (MW = 726.35 Da) and Lys-Glu-Glu-Lys-Phe-Glu $(\mathrm{MW}=808.40 \mathrm{Da})$, and the $\mathrm{IC}_{50}$ values of cellular antioxidant activity were $1.19 \pm 0.05 \mathrm{mg} / \mathrm{mL}$ and $1.04 \pm 0.06 \mathrm{mg} / \mathrm{mL}$. The results demonstrate that is possible to produce natural antioxidative peptides from Pacific herring protein via enzymatic hydrolysis and purification.
\end{abstract}

Keywords: pacific herring; protein hydrolysate; peptides; antioxidant activity; purification

\section{Introduction}

Antioxidant peptides, which contained residues 5-16 amino acid, are mainly produced through protein hydrolysis by enzyme. Antioxidative peptides from foods are considered to be safe and healthy compounds with low molecular weight, low cost, high activity, and easy absorption [1]. Reactive oxygen species (ROS) are generated by chemical reactions and metabolic processes, including tissue injury or DNA damage [2]. When the ROS or oxidants levels out of balance, it would cause numerous chronic diseases, including cancer, diabetes, et al. [3]. It has been reported that antioxidative peptides keep cells safe from damage by ROS through the induction of genes. Therefore, it is necessary to develop high antioxidant activity and safety antioxidant peptides from a nature food-based [4].

Antioxidant activity has been reported for protein hydrolysates prepared from various fish sources, such as capelin, mackerel, yellowfin sole, Alaska pollack, Atlantic salmon, hoki, conger eel, and scad [5]. Moreover, the researchers used many methods to measure the antioxidant activities of hydrolysates, and some researchers predicted the in vivo activity through the in vitro antioxidant activity assay, that has been questioned for a number of reasons [6]. As the best measures, animal and human models also have the disadvantage, including time-consuming, expensive and harsh experimental conditions [7]. Cell culture models provided an approach that is rapid and cost effective, and the model can reflect some phenomena, including distribution, regarding uptake and metabolism. Hepatocellular carcinoma (HepG2) cell line is a reliable model for evaluating the antioxidant activity 
of samples [8]. There are many studies have used HepG2 cells model to investigate the antioxidant effects of samples [9-11].

Pacific herring (Clupea pallasii) is distributed in the North Pacific and have critical ecological and commercial roles in oceanic and coastal waters [12]. Pacific herring is characterized by high content protein, population abundance, and low production cost. In recent decades, studies of Pacific herring, e.g., Hoyle and Merritt [13], have used different proteases to produce fish protein hydrolysates from whole Atlantic herring (Clupea harengus) and have investigated their characteristics; Sathivel et al. [14] studied the antioxidative properties of hydrolysed herring (C. harengus) and herring by-products. However, research on Pacific herring has been largely focused on resource quantity and distribution, and few studies of the preparation, purification and identification of Pacific herring have been conducted.

In this study, we used response surface method to optimize the hydrolytic condition of Pacific herring protein hydrolysate (PHPH), and the PHPH with molecular weights below 3500 Da were chosen as potential antioxidant peptide resources. Furthermore, the PHPH were separated using a series of chromatographic techniques and the amino acid sequences were identified, providing a theoretical basis for the high-value utilization of Pacific herring.

\section{Results and Discussion}

\subsection{Cytotoxic Effects of PHPH on HepG2 Cells}

An objective of this work was to investigate the effects of PHPH with different concentrations $(0.005-10 \mathrm{mg} / \mathrm{mL})$ on the cell viability of HepG2 cells in culture because high doses of PHPH can be toxic in cell culture systems [15]. As shown in Figure 1, the cell viability values were greater than $93 \%$ when the concentrations from $0.005 \mathrm{mg} / \mathrm{mL}$ to $10 \mathrm{mg} / \mathrm{mL}$, the result was close to the control group and exhibited that PHPH was almost non-toxic to HepG2 cells. Finally, the concentrations with above $90 \%$ cell viability were selected for further analyses.

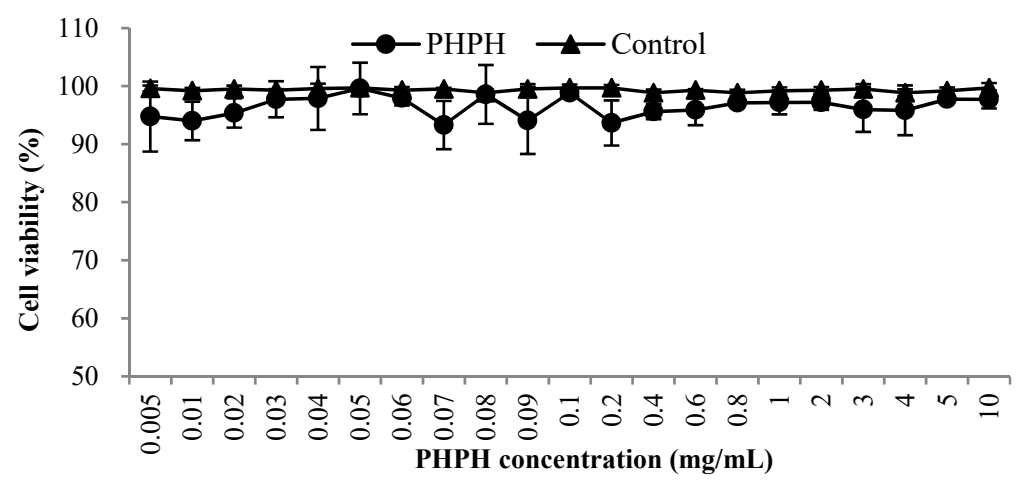

Figure 1. Toxic effects of PHPH on HepG2 cell viability. The PHPH was hydrolysed by trypsin.

\subsection{Selections of Proteolytic Enzymes}

In recent years, the enzymatic hydrolysis of proteins of marine organisms has been extensively studied to identify bioactive peptides [16]. Here, we used five proteases including pepsin, trypsin, papain, flavourzyme, and neutrase, for the hydrolytic production of $\mathrm{PHPH}$. The $\mathrm{H}_{2} \mathrm{O}_{2}$ was added in the HepG2 cells, and causing cells oxidative stress damage. The PHPH could clear hydroxyl radical from the $\mathrm{H}_{2} \mathrm{O}_{2}$ and protect the cells against oxidative damage. Then, we think the PHPH could protect the HepG2 cells via the effect of its antioxidative activity. In this section, the protease exhibited higher cellular antioxidant activity would be an optimum one for further research. As shown in Figure 2, PHPH $(10 \mathrm{mg} / \mathrm{mL})$ treated with trypsin exhibited the highest cellular antioxidant activity $(49.21 \% \pm 1.07 \%)$, followed by flavourzyme, neutrase, pepsin and papain. Therefore, trypsin was chosen as the optimum one for the next experiment. 


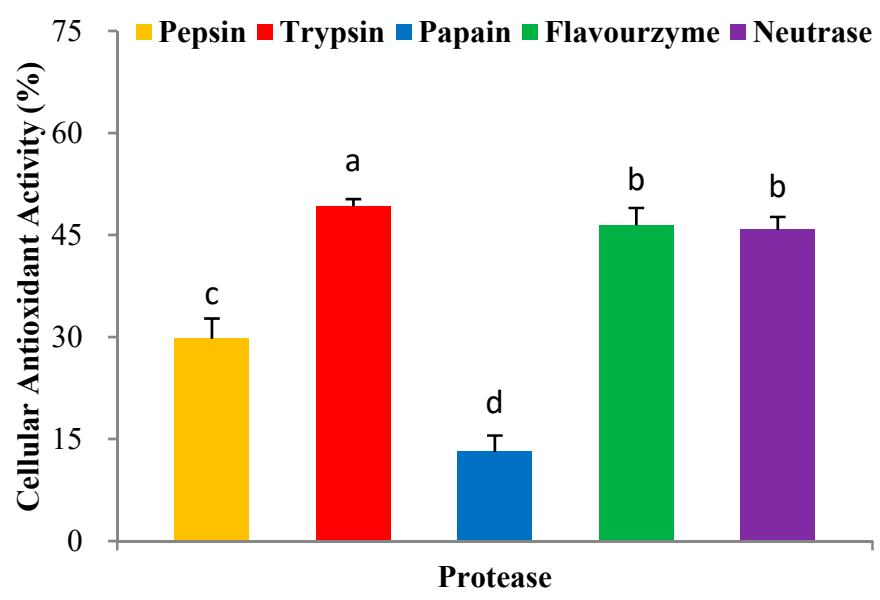

Figure 2. Cellular antioxidant activity of different enzymatic hydrolysis products. Bar graphs followed by different letters indicate significant differences $(p<0.05)$.

\subsection{Optimization of PHPH by Response Surface Methodology (RSM)}

In this work, a single-factor experiment was conducted to investigate the effects of hydrolysis conditions on cellular antioxidant activity; based on single-factor experiment, RSM was used to obtain the optimum conditions for the preparation of PHPH. As shown in Table 1, $\mathrm{X}_{1}, \mathrm{X}_{2}, \mathrm{X}_{3}, \mathrm{X}_{4}$ and $\mathrm{X}_{5}$ represented enzyme concentration $(\mathrm{U} / \mathrm{g})$, extraction time $(\mathrm{h}), \mathrm{pH}$, water/material ratio $(\mathrm{v} / \mathrm{w})$ and extraction temperature $\left({ }^{\circ} \mathrm{C}\right)$, respectively; and $\mathrm{Y}$ represented cellular antioxidant activity $(\%)$. The range of the cellular antioxidant activity of PHPH was from $25.73 \%$ to $43.22 \%$. The data were analysed via multiple regression analysis using Design-Expert software, which yielded the following polynomial equation:

$$
\begin{aligned}
Y & =+40.95+2.40 X_{1}+2.45 X_{2}+1.10 X_{3}+0.71 X_{4}+2.39 X_{5}+1.37 X_{1} X_{2}-0.81 X_{1} X_{3}-1.61 X_{1} X_{4}-2.45 X_{1} X_{5}-1.26 X_{2} X_{3} \\
& -1.08 X_{2} X_{4}+0.34 X_{2} X_{5}+0.077 X_{3} X_{4}-3.816 \times 10^{-3} X_{3} X_{5}+0.27 X_{4} X_{5}-4.09 X_{1}^{2}-0.11 X_{2}^{2}-2.59 X_{3}^{2}-1.47 X_{4}^{2}-3.51 X_{5}^{2}
\end{aligned}
$$

Table 1. Experimental design and result of response surface.

\begin{tabular}{ccccccc}
\hline Run Numbers & $\mathbf{X}_{\mathbf{1}}$ & $\mathbf{X}_{\mathbf{2}}$ & $\mathbf{X}_{\mathbf{3}}$ & $\mathbf{X}_{\mathbf{4}}$ & $\mathbf{X}_{\mathbf{5}}$ & $\mathbf{Y}$ \\
\hline 1 & 800 & 3 & 7 & 5 & 30 & 33.10 \\
2 & 1600 & 3 & 7 & 5 & 30 & 34.82 \\
3 & 800 & 7 & 7 & 5 & 30 & 36.03 \\
4 & 1600 & 7 & 7 & 5 & 30 & 43.22 \\
5 & 1200 & 5 & 5 & 1 & 30 & 36.64 \\
6 & 1200 & 5 & 9 & 1 & 30 & 38.06 \\
7 & 1200 & 5 & 5 & 9 & 30 & 36.34 \\
8 & 1200 & 5 & 9 & 9 & 30 & 37.15 \\
9 & 1200 & 3 & 7 & 5 & 20 & 32.29 \\
10 & 1200 & 7 & 7 & 5 & 20 & 36.03 \\
11 & 1200 & 3 & 7 & 5 & 40 & 37.60 \\
12 & 1200 & 7 & 7 & 5 & 40 & 42.72 \\
13 & 800 & 5 & 5 & 5 & 30 & 29.23 \\
14 & 1600 & 5 & 5 & 5 & 30 & 36.81 \\
15 & 800 & 5 & 9 & 5 & 30 & 33.86 \\
16 & 1600 & 5 & 9 & 5 & 30 & 38.19 \\
17 & 1200 & 5 & 7 & 1 & 20 & 34.06 \\
18 & 1200 & 5 & 7 & 9 & 20 & 35.43 \\
19 & 1200 & 5 & 7 & 1 & 40 & 35.63 \\
20 & 1200 & 5 & 7 & 9 & 40 & 35.73 \\
\hline
\end{tabular}


Table 1. Cont.

\begin{tabular}{ccccccc}
\hline Run Numbers & $\mathbf{X}_{\mathbf{1}}$ & $\mathbf{X}_{\mathbf{2}}$ & $\mathbf{X}_{\mathbf{3}}$ & $\mathbf{X}_{\mathbf{4}}$ & $\mathbf{X}_{\mathbf{5}}$ & $\mathbf{Y}$ \\
\hline 21 & 1200 & 3 & 5 & 5 & 30 & 32.55 \\
22 & 1200 & 7 & 5 & 5 & 30 & 37.85 \\
23 & 1200 & 3 & 9 & 5 & 30 & 37.93 \\
24 & 1200 & 7 & 9 & 5 & 30 & 40.54 \\
25 & 800 & 5 & 7 & 1 & 30 & 31.42 \\
26 & 1600 & 5 & 7 & 1 & 30 & 34.81 \\
27 & 800 & 5 & 7 & 9 & 30 & 31.34 \\
28 & 1600 & 5 & 7 & 9 & 30 & 34.55 \\
29 & 1200 & 5 & 5 & 5 & 20 & 31.51 \\
30 & 1200 & 5 & 9 & 5 & 20 & 32.90 \\
31 & 1200 & 5 & 5 & 5 & 40 & 33.42 \\
32 & 1200 & 5 & 9 & 5 & 40 & 37.82 \\
33 & 800 & 5 & 7 & 5 & 20 & 25.73 \\
34 & 1600 & 5 & 7 & 5 & 20 & 30.13 \\
35 & 800 & 5 & 7 & 5 & 40 & 36.72 \\
36 & 1600 & 5 & 7 & 5 & 40 & 40.38 \\
37 & 1200 & 3 & 7 & 1 & 30 & 34.52 \\
38 & 1200 & 7 & 7 & 1 & 30 & 41.03 \\
39 & 1200 & 3 & 7 & 9 & 30 & 42.03 \\
40 & 1200 & 7 & 7 & 9 & 30 & 43.22 \\
41 & 1200 & 5 & 7 & 5 & 30 & 39.07 \\
42 & 1200 & 5 & 7 & 5 & 30 & 38.99 \\
43 & 1200 & 5 & 7 & 5 & 30 & 42.80 \\
44 & 1200 & 5 & 7 & 5 & 30 & 39.49 \\
45 & 1200 & 5 & 7 & 5 & 30 & 42.14 \\
46 & 1200 & 5 & 7 & 5 & 30 & 41.14 \\
\hline & & & & & &
\end{tabular}

Analysis of variance (ANOVA) results were presented in Table 2. F value of the model was 15.34, and P value was less than 0.0001 , implying the model was significant and could be used for the optimization [17]. The variables with significant effects $(p<0.01)$ on the cellular antioxidant activity of PHPH were $X_{1}, X_{2}, X_{3}, X_{5}, X_{1} X_{4}, X_{1} X_{5}, X_{1}^{2}, X_{3}^{2}, X_{4}{ }^{2}$, and $X_{5}{ }^{2}$. The lack of fit value of 0.6059 indicated it was not significant relative to the pure error. The model showedgood fit with the experimental data, with high $\mathrm{R}^{2}(0.9246)$ and Adj. $\mathrm{R}^{2}(0.8643)$. These findings suggested that the hydrolysis of PHPH could be reliably analysed and predicted by the model.

Table 2. ANOVA for the response of cellular antioxidant activity in the PHPH.

\begin{tabular}{cccccc}
\hline Variables & Sum of Squares & DF & Mean Square & F Value & P Value \\
\hline Model & 601.75 & 20 & 30.09 & 15.34 & $<0.0001$ \\
Residual & 49.05 & 25 & 1.96 & & \\
Lack of fit & 38.51 & 20 & 1.93 & 0.91 & 0.6059 \\
Pure error & 10.53 & 5 & 2.11 & & \\
Cor total & 650.80 & 45 & & & \\
$\mathrm{R}^{2}$ & 0.9246 & & & & \\
Adj. $\mathrm{R}^{2}$ & 0.8643 & & & & \\
Pred. $\mathrm{R}^{2}$ & 0.7400 & & & & \\
Adeq precision & 17.822 & & & & \\
CV\% & 3.80 &
\end{tabular}

A 3D response surface was a graphical representation of a regression equation [18], the response surface plots revealed effects of two factors on cellular antioxidant activity; the effects of the remaining factors were maintained at zero [19]. The response surface plots would suggest well-defined optimum conditions when their shapes were convex [20]. 
The results presented in Figure $3 \mathrm{~A}$ showed that cellular antioxidant activity increased as $\mathrm{X}_{1}$ increased from $800 \mathrm{U} / \mathrm{g}$ to $1300 \mathrm{U} / \mathrm{g}$ and decreased slightly as $\mathrm{X}_{1}$ increased from $1300 \mathrm{U} / \mathrm{g}$ to $1600 \mathrm{U} / \mathrm{g}$, indicating that $X_{1}$ was a critical factor in enzymatic hydrolysis. This finding was consistent with the report of Batista et al. [21] that an increase in $\mathrm{X}_{1}$ might result in a reduced rate of hydrolysis. Additionally, when the $X_{2}$ increased from $3 \mathrm{~h}$ to $7 \mathrm{~h}$, the cellular antioxidant activity increased slightly, and the same trend was shown in Figure 3E-G.

Figure $3 \mathrm{~B}, \mathrm{E}, \mathrm{H}, \mathrm{I}$ showed that the cellular antioxidant activity increasing slightly when $\mathrm{X}_{3}$ increased from 5.0 to 9.0 , and then plateaued. Maximum cellular antioxidant activity was achieved when $X_{1}$ and $\mathrm{X}_{3}$ were $1450 \mathrm{U} / \mathrm{g}$ and 7.0, respectively.

According to Figure $3 C$, as the $X_{4}$ increased from 1 to 9 , the cellular antioxidant activity increased slightly, and the same trend was shown in Figure 3F. Additionally, the cellular antioxidant activity initially increased and then decreased slightly as the $X_{4}$ increased from 1 to 9 , as shown in Figure $3 \mathrm{H}, \mathrm{J}$. We speculated that a higher $X_{4}$ may dilute the $X_{1}$ and slow the rate of enzyme reactions [22].

Figure $3 \mathrm{D}$, showed that as the $\mathrm{X}_{5}$ increased from $20^{\circ} \mathrm{C}$ to $40{ }^{\circ} \mathrm{C}$, the cellular antioxidant activity increased significantly. Feng et al. [19] reported that increases in temperature helped disperse the solutes and increase yield. Maximum cellular antioxidant activity was achieved when $X_{1}$ and $X_{5}$ were $1400 \mathrm{U} / \mathrm{g}$ and $32{ }^{\circ} \mathrm{C}$, respectively.

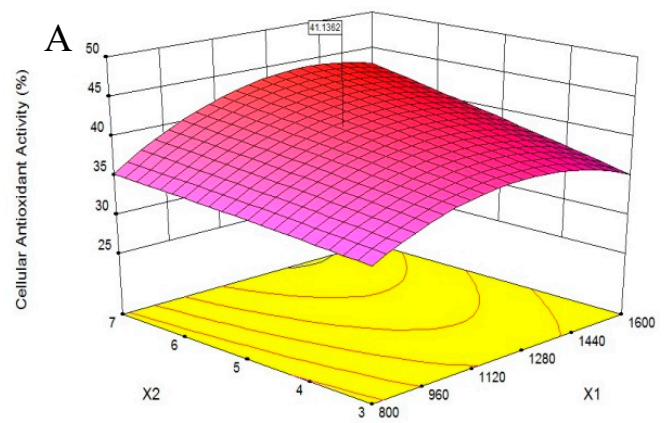

B
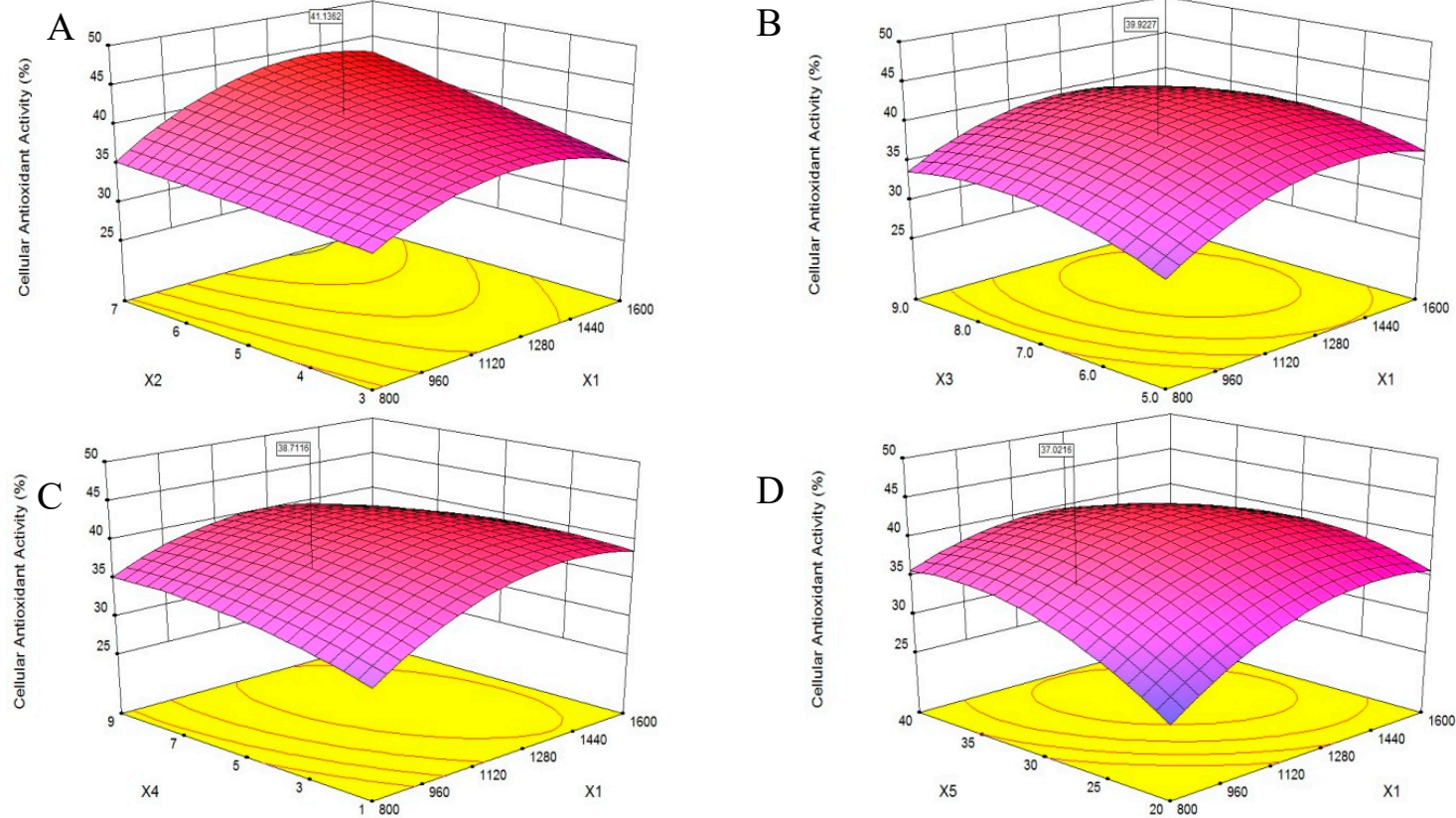

$\mathrm{D}$
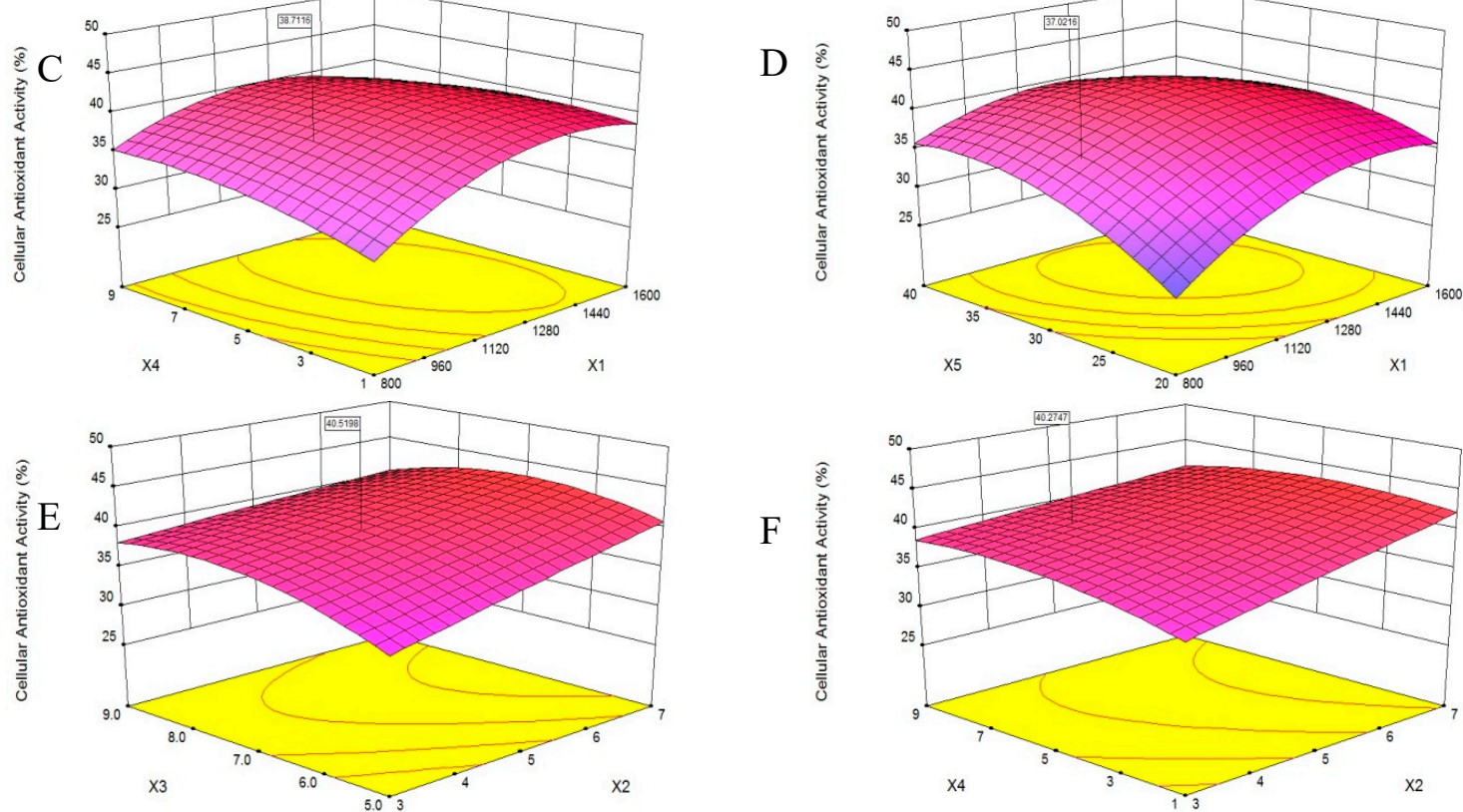

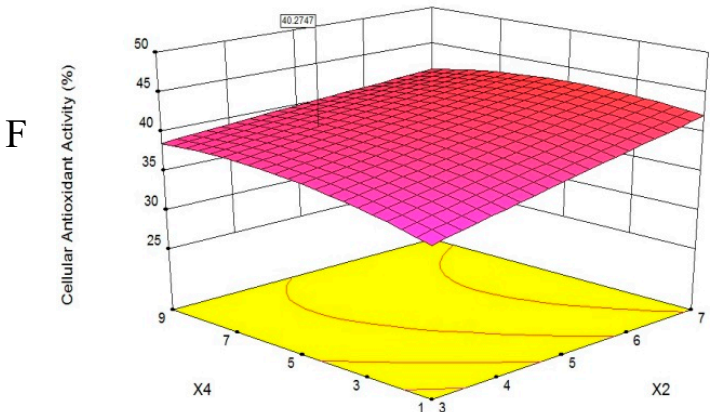

Figure 3. Cont. 
G

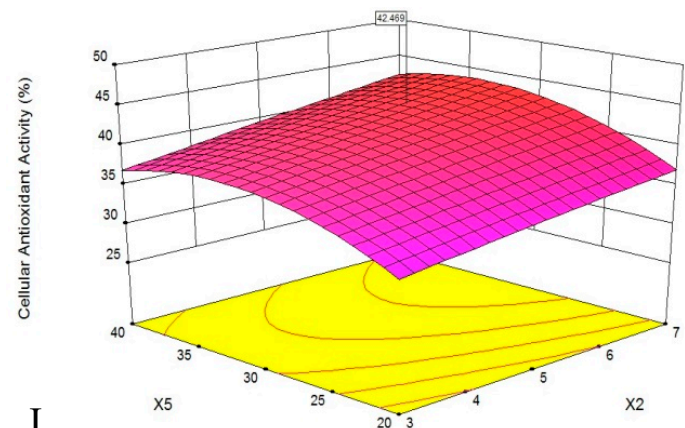

$$
\text { I }
$$

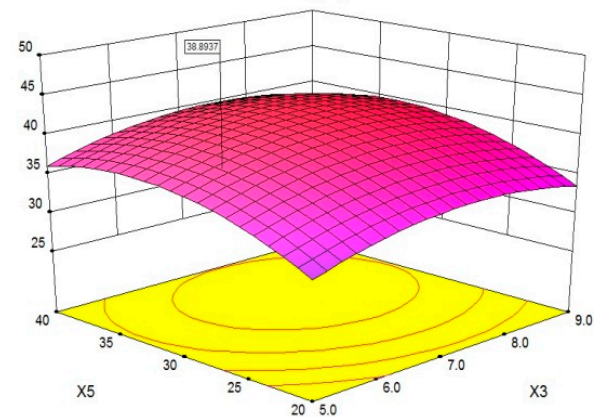

$\mathrm{H}$

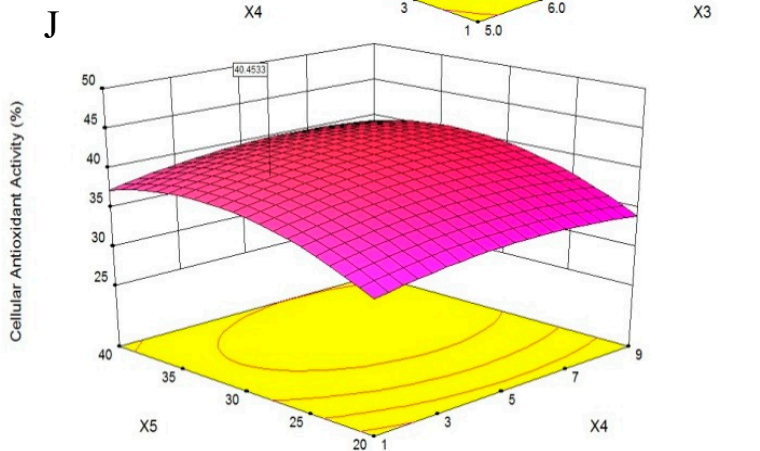

Figure 3. Response surface plots on the cellular antioxidant activity of PHPH. $X_{1}, X_{2}, X_{3}, X_{4}$ and $X_{5}$ represent enzyme concentration, extraction time, $\mathrm{pH}$, water/material ratio and extraction temperature. Figures (A-J) meant the response surface plots displayed the effects of two factors on cellular antioxidant activity.

The optimum level of cellular antioxidant activity, $44.56 \%$, was achieved at $X_{1}$ of $1394.02 \mathrm{U} / \mathrm{g}, \mathrm{X}_{2}$ of $7.0 \mathrm{~h}, \mathrm{X}_{3}$ of $6.78, \mathrm{X}_{4}$ of $3.51 \mathrm{v} / \mathrm{w}$ and $\mathrm{X}_{5}$ of $32.06{ }^{\circ} \mathrm{C}$. The experimental cellular antioxidant activity value agreed with the value predicted by the model within a $95 \%$ confidence interval. This model was suitable for the estimation of experimental values and useful for the optimization predictions of the extraction. The extraction yield of PHPH under this condition was $18.49 \mathrm{~g} /(100 \mathrm{~g}$ original herring protein).

\subsection{Amino Acid Composition of PHPH}

The antioxidative activity of a protein hydrolysate fraction could be affected by the amino acid composition [23].

As shown in Table 3, the PHPH was rich in Glu, Asp, Leu, Lys, and Arg. Some studies have reported that Arg, Glu, Leu, and Asp can enhance the antioxidant activity of peptides [24,25]. Additionally, the ratios of $\sum E A A / \sum N E A A$ and $\sum E A A / \sum A A$ in $\mathrm{PHPH}$ were 0.70 and 0.41 , respectively; and the $\mathrm{FAO} / \mathrm{WHO}$ recommended values were 0.6 and 0.4 , respectively. The results exhibited that the PHPH contained abundant amino acids and could be the desirable antioxidative peptides.

Table 3. Amino acid composition of PHPH.

\begin{tabular}{cc}
\hline Amino Acid & Content (\%) \\
\hline Asp & 4.93 \\
Thr $^{*}$ & 2.26 \\
Ser & 2.19 \\
Glu & 6.22 \\
Gly & 3.5 \\
Ala & 2.78 \\
Gys & 0.11 \\
\hline
\end{tabular}


Table 3. Cont.

\begin{tabular}{cc}
\hline Amino Acid & Content (\%) \\
\hline Val $^{*}$ & 2.95 \\
Met $^{*}$ & 1.14 \\
Ile * $^{*}$ & 2.45 \\
Leu $^{*}$ & 4.43 \\
Tyr & 1.07 \\
Phe * & 2.43 \\
Lys * & 4.3 \\
His & 1.35 \\
Arg & 4.01 \\
Pro & 2.37 \\
$\sum$ AA & 48.49 \\
$\sum E A A$ & 19.96 \\
$\sum E A A / \sum N E A A$ & 0.70 \\
$\sum E A A / \sum A A$ & 0.41 \\
\hline
\end{tabular}

* expressed essential amino acids; $\overline{\sum A A}$ expressed total amino acid content; $\sum E A A$ expressed essential amino acid content; $\sum$ NEAA expressed non-essential amino acid content.

\subsection{Purification of $\mathrm{PHPH}$}

\subsubsection{Fractions of PHPH by Ultrafiltration}

PHPH was fractioned by ultrafiltration with two MWCO membranes (10,000 Da and $3500 \mathrm{Da})$. Three fractions were separated and named PHPH-I (MW > 10,000 Da), PHPH-II (MW = 3500-10,000 Da) and PHPH-III (MW < 3500 Da). The yield of PHPH-III was 85.46g/(100 g PHPH). Half maximal inhibitory concentration $\left(\mathrm{IC}_{50}\right)$ values of these fractions were given in Figure 4, PHPH-III showed the highest hydroxyl radical scavenging activity, with $\mathrm{IC}_{50}$ value of $7.91 \pm 0.13 \mathrm{mg} / \mathrm{mL}$. The 1,1-dipheny-2picryhydrazyl (DPPH) radical scavenging activity of PHPH-I, PHPH-II and PHPH-III were $13.56 \pm 0.34$, $8.87 \pm 0.33$ and $7.05 \pm 0.15 \mathrm{mg} / \mathrm{mL}$, respectively. Furthermore, the $\mathrm{IC}_{50}$ value of cellular antioxidant activity in PHPH-III was $7.90 \pm 0.33 \mathrm{mg} / \mathrm{mL}$, which was significantly higher than the activities in PHPH-I and PHPH-II of $10.26 \pm 0.69$ and $9.04 \pm 0.23 \mathrm{mg} / \mathrm{mL}$, respectively.

These results were consistent with Wang et al., who reported that peptides with molecular weights below 3000 Da derived from blue mussel (Mytilus edulis) protein hydrolysate exhibited higher antioxidant activity than did those with higher molecular weights [26]. It has been reported that the molecular weight distribution can affect the antioxidant activity of hydrolysates, and the peptides with lower molecular weights can cross the intestinal barrier more easily than those with higher weights to exert their biological effects [27].

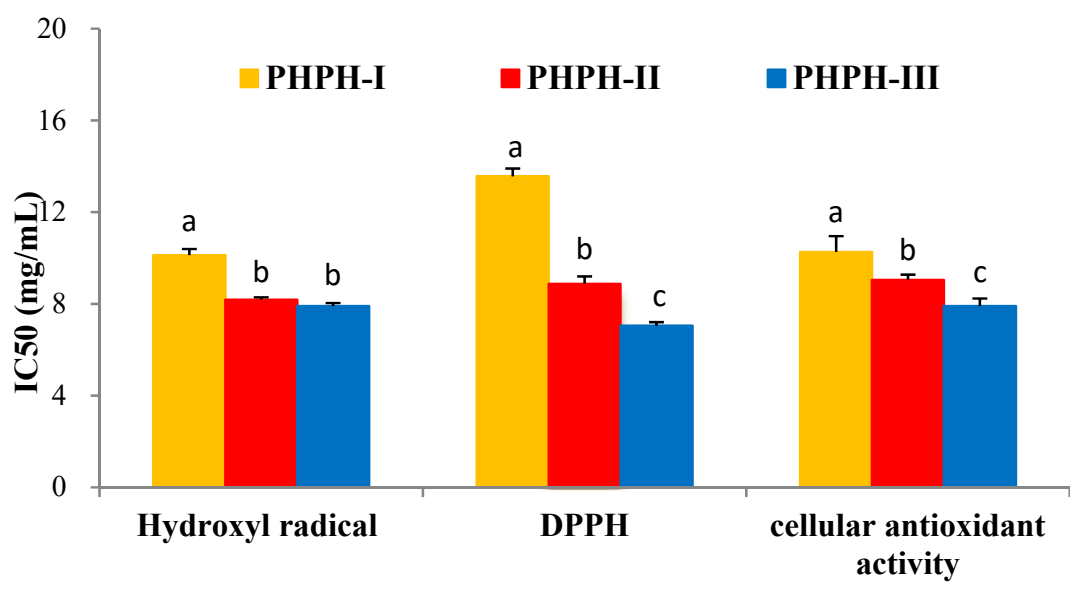

Figure 4. Antioxidant activities of different fractions from PHPH. Bar graphs followed by different letters indicated significant differences $(p<0.05)$. 


\subsubsection{Gel Filtration Chromatography of PHPH-III}

PHPH-III, which was obtained by treatment with ultrafiltration and displayed the highest cellular antioxidant activity among the fractions, was further fractioned by a Sephadex G-25 gel filtration column. The fractions were separated and designated F1-F10 (Figure 5A). These fractions were collected, freeze-dried, and determined the cellular antioxidant activities. As shown in Figure 5B, fraction F5 exhibited the highest level of cellular antioxidant activity with the $\mathrm{IC}_{50}$ value of $3.21 \pm 0.15 \mathrm{mg} / \mathrm{mL}$. The yield of PHPH-III-5 was 20.16 mg/(250 mg PHPH-III).

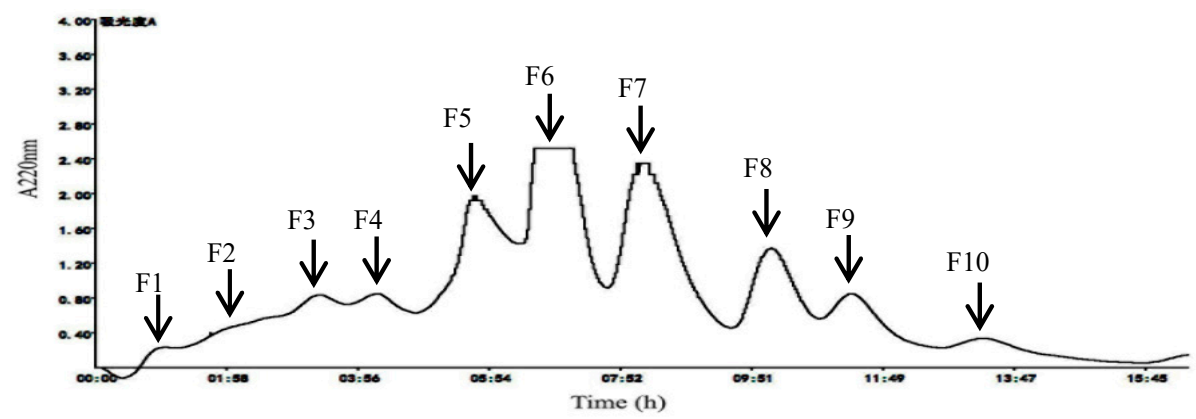

(A)

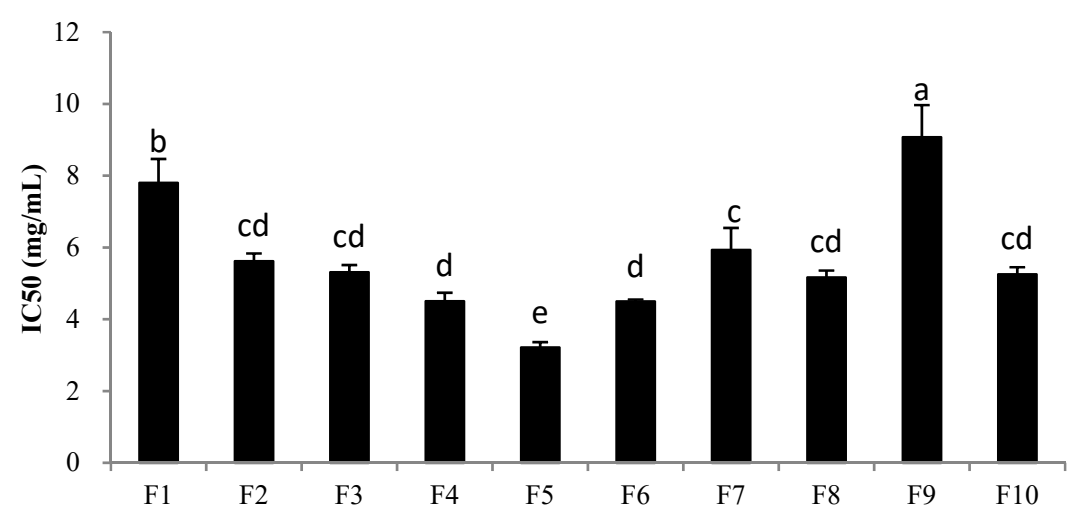

(B)

Figure 5. Separation chromatogram for the PHPH-III by a Sephadex G-25 gel filtration column (A) and cellular antioxidant activity of the eluted peak (B). Bar graphs followed by different letters indicated significant differences $(p<0.05)$. Fractions F1-F10 were separated from Sephadex G-25 gel filtration column.

\subsubsection{RP-HPLC Analysis}

An XBridge®BEH C18 column was used for further purification of the fraction PHPH-III-5. As shown in Figure 6, 6 peaks, designated F1-F6, were collected separately. Each fraction was freeze-dried and determined the cellular antioxidant activities. The result showed that $\mathrm{F} 2$ exhibited the highest cellular antioxidant activity with the $\mathrm{IC}_{50}$ value of $1.33 \pm 0.02 \mathrm{mg} / \mathrm{mL}$ (Figure $6 \mathrm{~B}$ ); this activity was significantly higher than the activities of the other fractions at the same concentration $(p<0.05)$. The yield of PHPH-III-5-2 was 2.56 mg/(20 mg PHPH-III-5). 


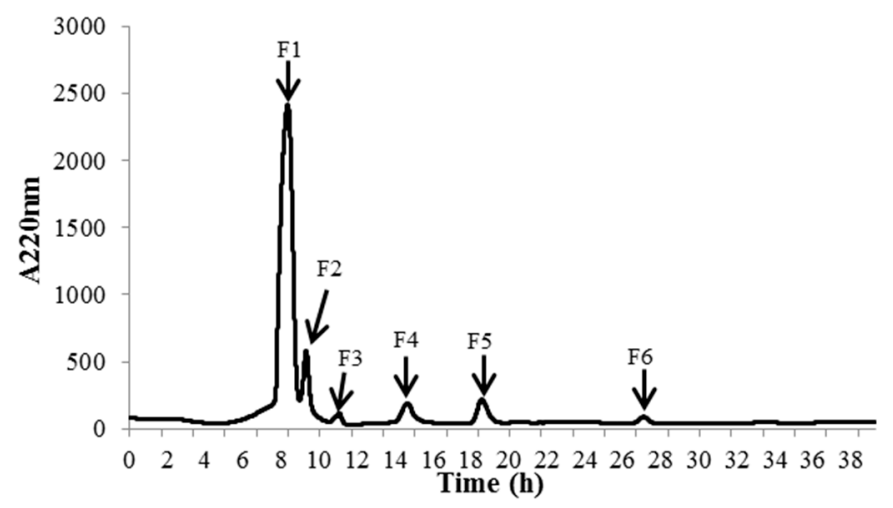

(A)

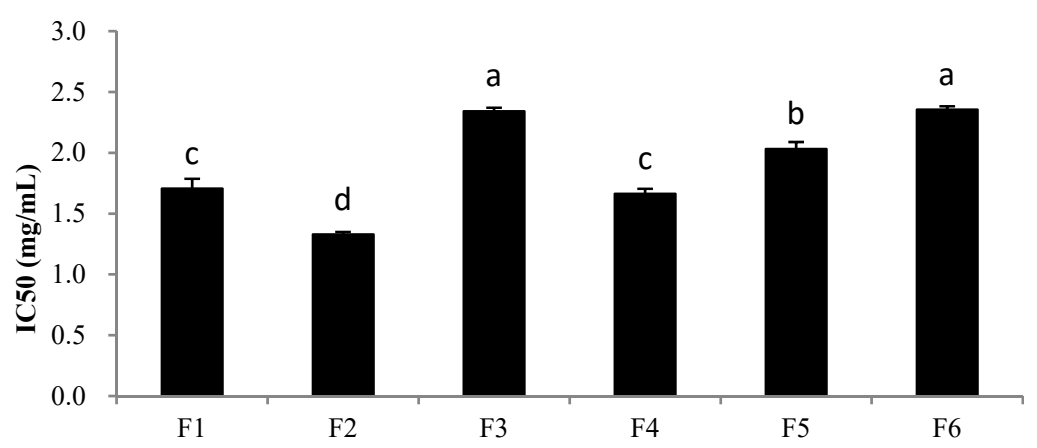

(B)

Figure 6. Separation chromatogram for the PHPH-III-5 by an XBridge®BEH C18 column (A) and cellular antioxidant activity of the eluted peaks (B). Bar graphs followed by different letters indicated significant differences $(p<0.05)$. Fractions F1-F6 were separated from XBridge®BEH C18 column.

\subsection{Characterization of $\mathrm{PHPH}$}

To identify the antioxidative peptide, the mass spectrometer used to analyse PHPH-III-5-2. As shown in Figures 7 and 8, two high-score peptides, P1 and P2 were obtained. The MS/MS spectrum of two charged ions with $\mathrm{m} / \mathrm{z}$ at 364.18 Da and 405.21 Da were shown in Figures 7B and 8B, respectively, and the molecular weight of peptides P1 and P2 were determined to be $726.35 \mathrm{Da}$ and $808.40 \mathrm{Da}$, respectively. Additionally, the amino acid sequence of peptide P1 was identified as Leu-His-Asp-Glu-Leu-Thr and peptide P2 was identified as Lys-Glu-Glu-Lys-Phe-Glu.

Additionally, to evaluate the antioxidant activities of P1 and P2, the cellular antioxidant activity and radical scavenging activities were investigated. As shown in Table 4, P1 exhibited the hydroxyl radical scavenging activity, DPPH radical scavenging activity, and cellular antioxidant activity with the $\mathrm{IC}_{50}$ values of $4.57 \pm 0.24 \mathrm{mg} / \mathrm{mL}, 5.14 \pm 0.32 \mathrm{mg} / \mathrm{mL}$, and $1.19 \pm 0.05 \mathrm{mg} / \mathrm{mL}$, respectively; P2 exhibited higher antioxidant activities than $\mathrm{P} 1$, the $\mathrm{IC}_{50}$ values were $3.78 \pm 0.17 \mathrm{mg} / \mathrm{mL}, 4.37 \pm 0.26 \mathrm{mg} / \mathrm{mL}$, and $1.04 \pm 0.06 \mathrm{mg} / \mathrm{mL}$, respectively. Research findings indicated that peptides with 2-6 amino acids were absorbed more readily in comparison to protein and free amino acids [1]. Yang et al. [28] had identified the protein hydrolysate of Hairtail (Trichiurus japonicas) muscle, and the $\mathrm{EC}_{50}$ values of DPPH scavenging activities were $0.626 \mathrm{mg} / \mathrm{mL}$ to $0.902 \mathrm{mg} / \mathrm{mL}$; Najafian et al. [29] had studied the peptide from fermented fish (pekasam) and the identified peptides exhibited the $\mathrm{IC}_{50}$ values of DPPH scavenging activities were $0.897 \mathrm{mg} / \mathrm{mL}$ and $1.38 \mathrm{mg} / \mathrm{mL}$, respectively. 


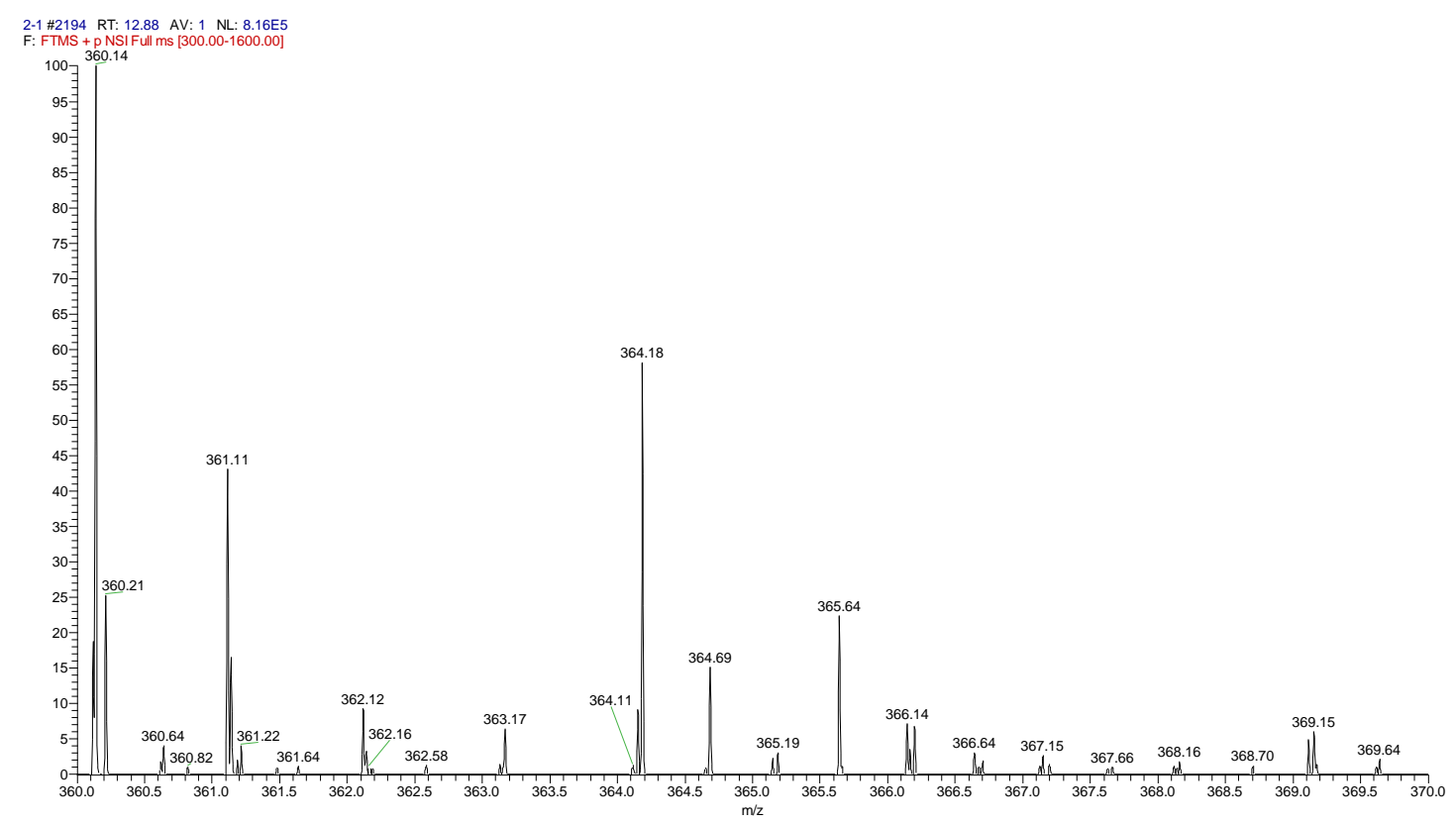

(A)

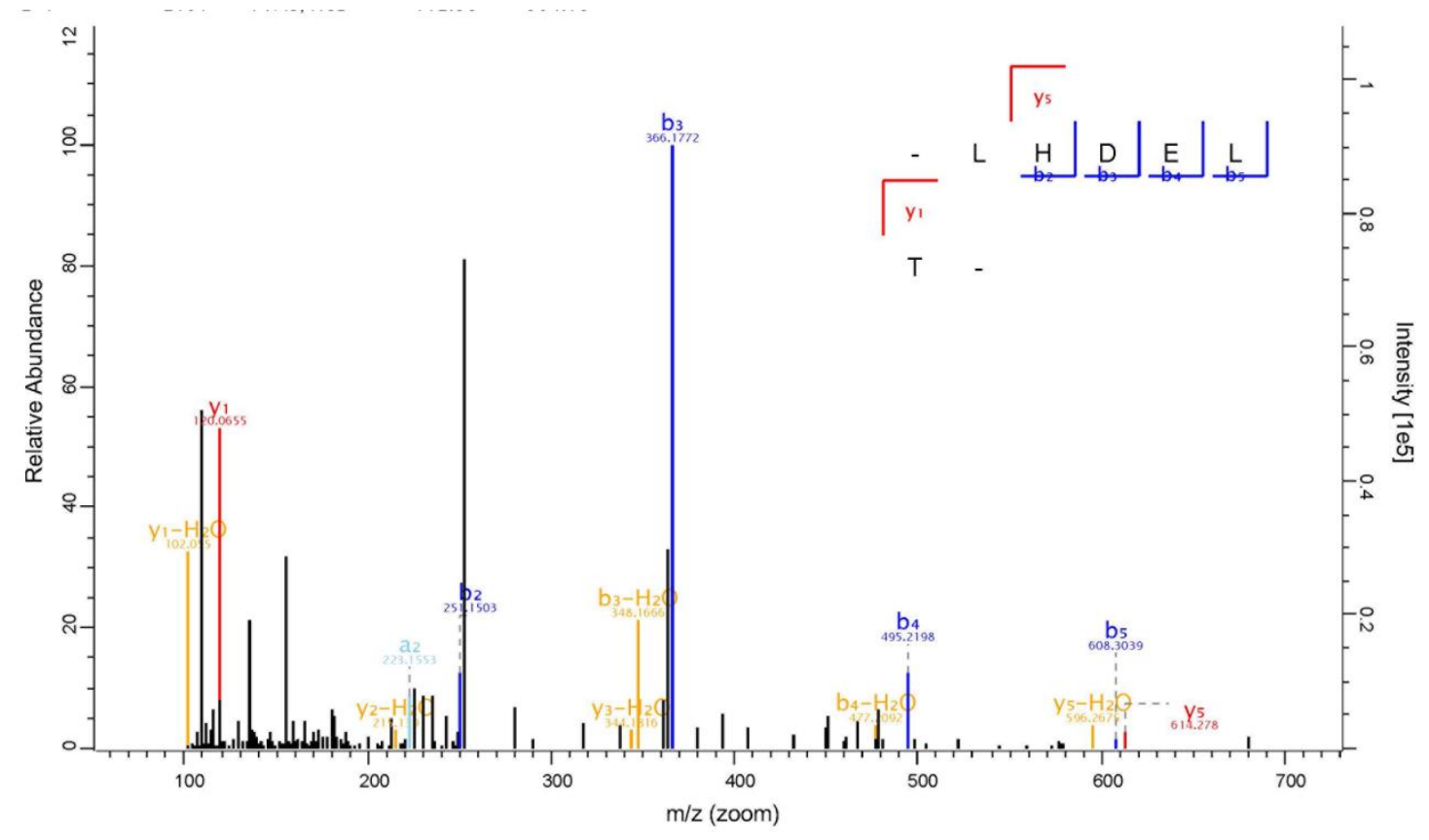

(B)

Figure 7. Identification of the peptide P1 from PHPH-III-5-2. Mass spectrum of the chromatographic P1 (A), and the collision induced fragmentation of P1 (B). The sequence of P1 was displayed with the fragment ions observed in the MS/MS spectrum. 


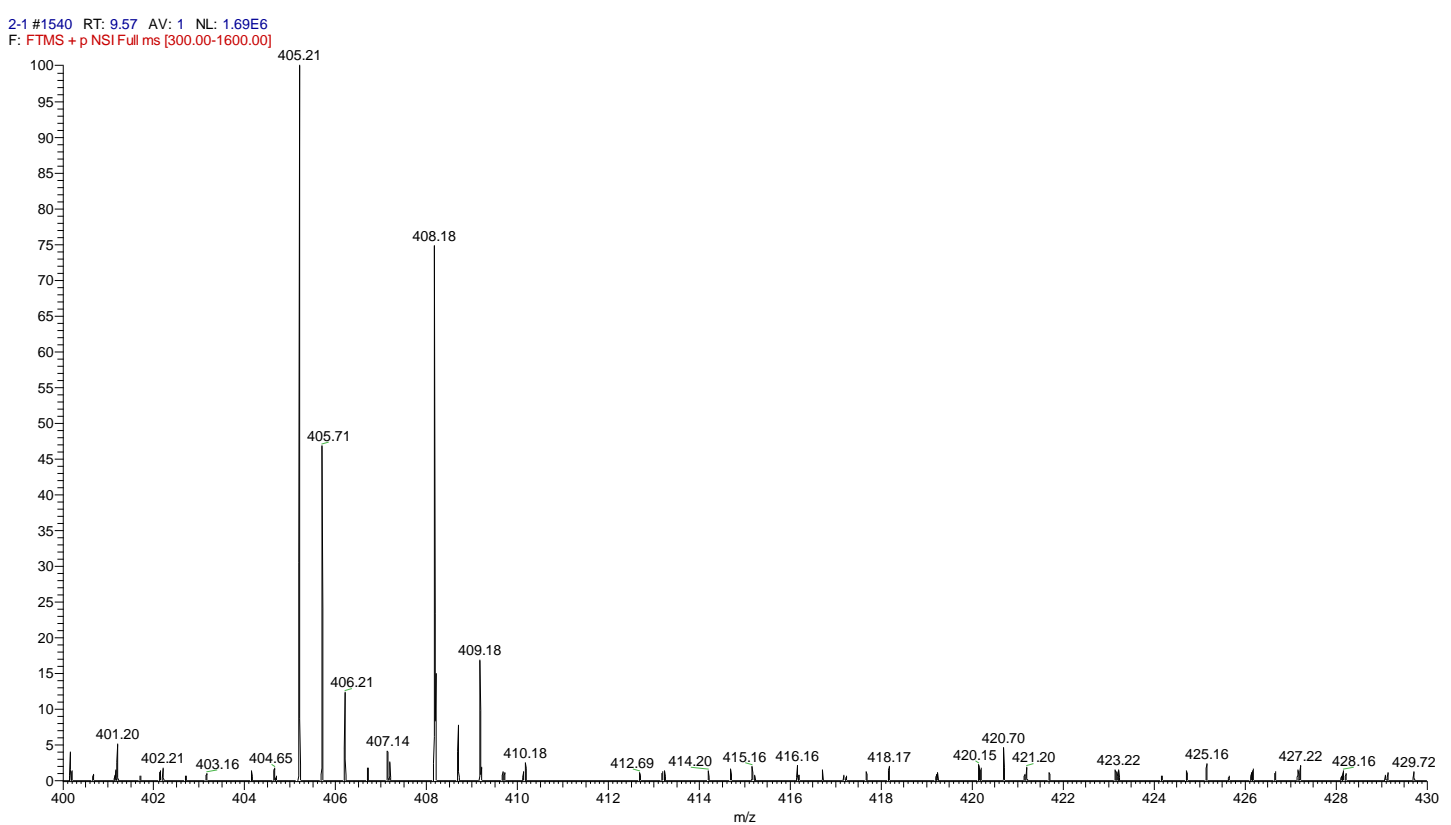

(A)

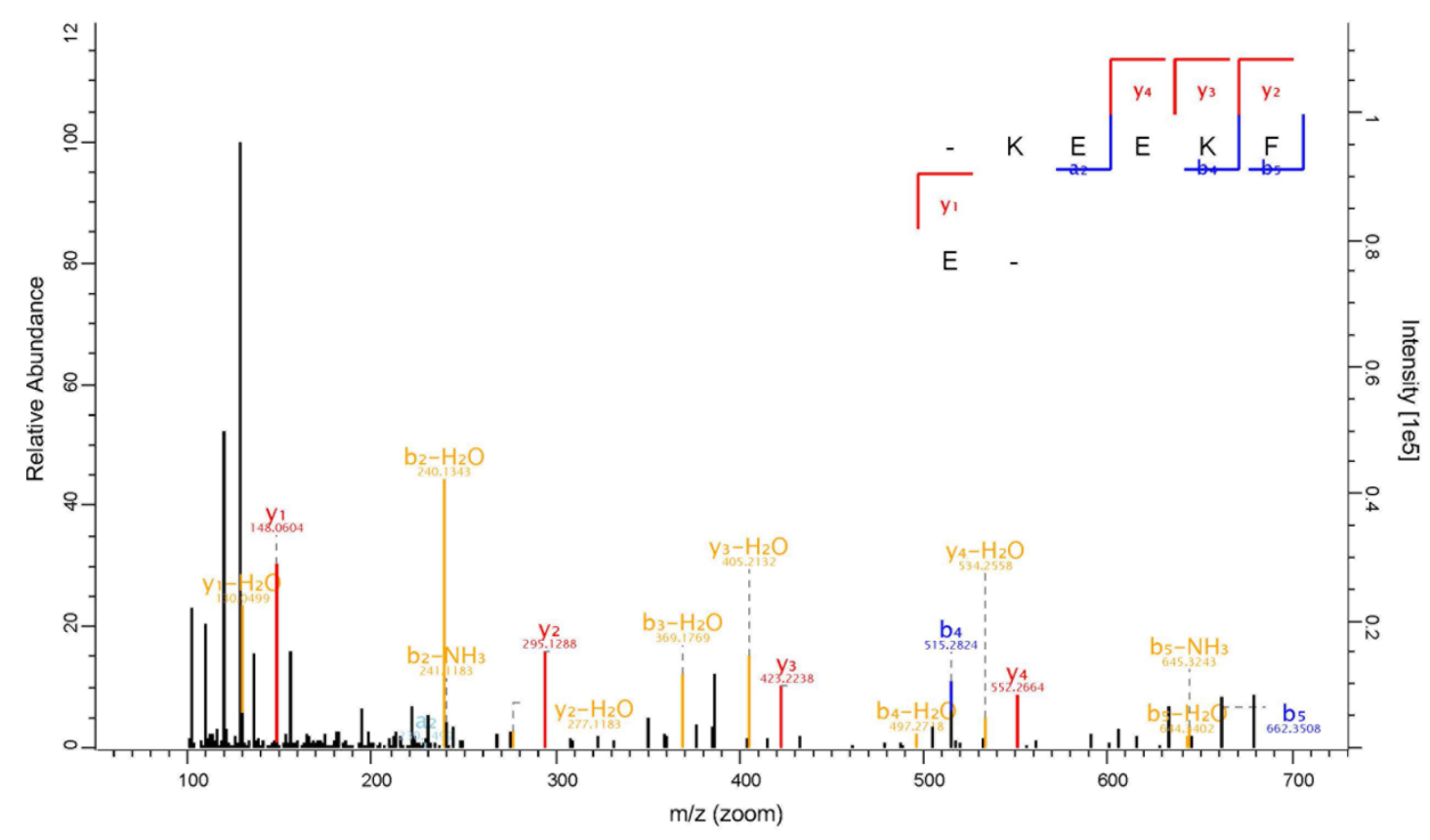

(B)

Figure 8. Identification of the peptide P2 from PHPH-III-5-2. Mass spectrum of the chromatographic P1 (A), and the collision induced fragmentation of P2 (B). The sequence of P2 was displayed with the fragment ions obse.rved in the MS/MS spectrum.

Many studies have reported that the antioxidative activity of peptides can be affected by the amino acid sequence [30]. For example, Leu could enhance the scavenging activities of peptides [31,32]; Kim et al. and Rajapakse et al. [33,34] studied the activities of individual amino acids and reported that Glu, Lys and Phe consistently showed higher antioxidant activity than the other amino acids. Furthermore, peptides P1 and P2 contained the amino acids related to antioxidant activity, which was consistent with those reported from other studies from fish sources [35-37]. 
Table 4. $\mathrm{IC}_{50}$ values of $\mathrm{P} 1$ and $\mathrm{P} 2$.

\begin{tabular}{cccc}
\hline \multirow{2}{*}{ Sample } & \multicolumn{3}{c}{ IC $_{\mathbf{5 0}}(\mathbf{m g} / \mathbf{m L})$} \\
\cline { 2 - 4 } & Hydroxyl Radical Scavenging Activity & DPPH Radical Scavenging Activity & Cellular Antioxidant Activity \\
\hline P1 & $4.57 \pm 0.24$ & $5.14 \pm 0.32$ & $1.19 \pm 0.05$ \\
P2 & $3.78 \pm 0.17$ & $4.37 \pm 0.26$ & $1.04 \pm 0.06$ \\
\hline
\end{tabular}

\section{Materials and Methods}

\subsection{Materials and Chemicals}

Individuals of Pacific herring (Clupea pallasii) were purchased from a seafood market in Qingdao, China. Whole fish were transported on ice to the laboratory. Upon arrival, the fish were washed, and the fish meat was collected, minced, and freezed. Five proteases (papain, flavourzyme, pepsin, trypsin, and neutrase) were obtained from Solarbio Co. (Beijing, China). An ultrafiltration (UF) system and UF membranes were buy from Laungy Co., Ltd. (Shanghai, China). Hepatocellular carcinoma (HepG2) cells were obtained from Qingdao University (Shandong, China). Trifluoroacetic acid (TFA), acetonitrile, formic acid and methanol were of guaranteed reagent and purchased from Sigma Chemical Co. (St Louis, MO, USA). All other chemicals and solvents were of analytical reagent, and purchased from Sinopharm Chemical Reagent Co., Ltd (Shanghai, China).

\subsection{Preparation of $\mathrm{PHPH}$}

Five proteases were studied to determine the optimal enzyme. The Pacific herring protein was mixed with deionized water at a ratio of 1:10 $\mathrm{v} / \mathrm{w}$. The mixtures were adjusted to the required $\mathrm{pH}$ with $0.01 \mathrm{~mol} / \mathrm{L} \mathrm{NaOH}$ or $\mathrm{HCl}$ and heated in a water bath to the required temperature before proteases were added in a proper proportion based on enzyme activity. After reaction finished, the mixtures were heated for $15 \mathrm{~min}$ at $100^{\circ} \mathrm{C}$ in order to end up hydrolysis followed by centrifugation at $18,000 \times g$ for $10 \mathrm{~min}$ and the supernatants were concentrated and freeze-dried. The cellular antioxidant activities of five enzymatic hydrolysis products with the concentration of $10 \mathrm{mg} / \mathrm{mL}$ were determined.

The protease, which exhibited the highest cellular antioxidant activity, would be chosen for the next experiment. Additionally, we used RSM to obtain the optimum hydrolysis conditions [38].

\subsection{Optimization of PHPH Preparative Conditions}

It was important to choose suitable variables with appropriate levels before conducting the RSM experiment [39]. Generally speaking, there were five enzymatic hydrolysis reaction variables, such as extraction temperature, enzyme concentration, extraction time, $\mathrm{pH}$ and water/material ratio. Firstly, we used single-factor experiment to confirm the appropriate level, and then used the Box-Behnken design (BBD) to design the experiment, each variable contained five levels, and the designed experiment had 46 runs.

\subsection{Amino Acid Analysis}

The amino acid analysis method was in accordance with Luo et al. [40]. The PHPH was hydrolysated with $6 \mathrm{~mol} / \mathrm{L} \mathrm{HCl}$ at $110{ }^{\circ} \mathrm{C}$ for $24 \mathrm{~h}$, and constant volume to $50 \mathrm{~mL}$. Then, $1 \mathrm{ml}$ sample suck to evaporate, then dissolved with water and evaporated, the residue was diluted with $1 \mathrm{~mL}$ of buffer ( $\mathrm{pH}$ 2.2) and detected with a S433D amino acid analyser (SYKAM, Eresing, Munich, Germany). This method could detect sixteen amino acids without tryptophan because of acid hydrolysis oxidise.

\subsection{Antioxidant Analysis of HepG2 Cells}

\subsubsection{Cytotoxic Effects of PHPH on HepG2 Cells}

HepG2 cells are always used for evaluating the antioxidant activity of samples [41]. We used methyl thiazolyl tetrazolium (MTT) assay to measure the inhibition of HepG2 [10]. The cells were 
cultivated in 96-well culture plates at the optimal temperature and humidity for $24 \mathrm{~h}$. Next, the PHPH with different concentrations $(100 \mu \mathrm{L})$ were added in the cells for another $24 \mathrm{~h}$, and each well was added $20 \mu \mathrm{L}$ of MTT for $3 \mathrm{~h}$. Then, $150 \mu \mathrm{L}$ dimethyl sulfoxide (DMSO) was added into the well and shaken for $10 \mathrm{~min}$. Finally, we used a microplate reader (Bio-Rad, California, USA) to obtain the absorbance at a wavelength of $490 \mathrm{~nm}$. The experiment was repeated 4 times.

\subsubsection{Cellular Antioxidant Activity Determination}

The cells were cultivated in 96-well culture plates at the optimal temperature and humidity for $24 \mathrm{~h}$. Firstly, the PHPH $(100 \mu \mathrm{L})$ with different concentrations were added in the cells for another $24 \mathrm{~h}$, and then $1000 \mu \mathrm{M} \mathrm{H}_{2} \mathrm{O}_{2}(100 \mu \mathrm{L})$ was added for another $24 \mathrm{~h}$. The MTT assay as described above was used to measure the viability of HepG2 to evaluate the cellular antioxidant activity of PHPH, in this section, the cellular antioxidant activity was defined as cell viability:

Cell viability $(\%)=\left(\mathrm{A}_{1}-\mathrm{A}_{0}\right) /\left(\mathrm{A}_{2}-\mathrm{A}_{0}\right) \times 100$, where $\mathrm{A}_{1}$ is the absorbance with $\mathrm{PHPH}$ and $\mathrm{H}_{2} \mathrm{O}_{2}$ ， $\mathrm{A}_{2}$ is the absorbance without $\mathrm{PHPH}$ and $\mathrm{H}_{2} \mathrm{O}_{2}$, and $\mathrm{A}_{0}$ is the absorbance with $\mathrm{H}_{2} \mathrm{O}_{2}$. The experiment was repeated 4 times.

\subsection{Hydroxyl Radical Scavenging Activity}

We measured the hydroxyl radicals scavenging activity of $\mathrm{PHPH}$ followed the description of Smeriglio et al. [42]. Various concentrations of the PHPH were mixed with $0.5 \mathrm{~mL}$ of $\mathrm{EDTA}_{-\mathrm{FeSO}}$

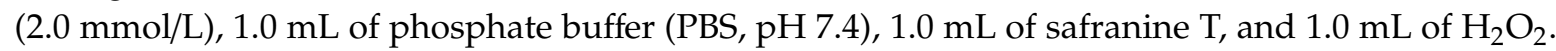
The control group was added PBS replaced $\mathrm{H}_{2} \mathrm{O}_{2}$. After mixing and incubation for $60 \mathrm{~min}$ in $37^{\circ} \mathrm{C}$, absorbance was measured spectrophotometrically at $520 \mathrm{~nm}$. The hydroxyl radicals scavenging activity was calculated according to the following equation,

Hydroxyl radical scavenging activity $(\%)=\left(\mathrm{A}_{\text {sample }}-\mathrm{A}_{\text {blank }}\right) /\left(\mathrm{A}_{\text {control }}-\mathrm{A}_{\text {blank }}\right) \times 100$. Half maximal inhibitory concentration of hydroxyl radical was used to calculate the antioxidant activity of sample.

\subsection{DPPH Radical Scavenging Activity}

The DPPH radical assay is a simple and rapid method to test the scavenging activity of sample. We measured the DPPH radicals scavenging activity of PHPH followed the description of Blois [43]. $1.0 \mathrm{~mL}$ of DPPH solution $(0.1 \mathrm{mM}$, dissolved in ethanol) was mixed with $3.0 \mathrm{~mL}$ of PHPH or distilled water in a test tube, after mixing and incubation for $30 \mathrm{~min}$, the absorbance was determined at $517 \mathrm{~nm}$. The blank group containing distilled water and ethanol. The DPPH radical scavenging activity was calculated according to the following equation,

DPPH radical scavenging activity $(\%)=\left(\mathrm{A}_{\text {control }}-\mathrm{A}_{\text {sample }}\right) /\left(\mathrm{A}_{\text {control }}-\mathrm{A}_{\text {blank }}\right) \times 100$. Half maximal inhibitory concentration of DPPH radical was used to calculate the antioxidant activity of sample.

\section{8. $I C_{50}$ Values Determination}

$\mathrm{IC}_{50}$ values, defined as the concentration of $\mathrm{PHPH}(\mathrm{mg} / \mathrm{mL})$ required inhibiting $50 \%$ of cellular antioxidant activity or radical scavenging activity, were determined by nonlinear regression from a plot of analysis of cellular antioxidant activity or radical scavenging activity versus the PHPH concentrations (SPSS 16.0 statistic software).

\subsection{Purification of PHPH}

\subsubsection{Ultrafiltration}

UF is often used to separate hydrolysates to obtain the target active fractions [44]. The PHPH was fractionated through UF membranes have a range of molecular weight cut-offs (MWCOs) of 10,000 Da and 3500 Da, respectively. Fractionates were designed as follows: PHPH-I (>10,000 Da), PHPH-II 
(3500-10,000 Da) and PHPH-III (<3500 Da). All fractions were frozen drying and refrigerated for further experiment.

\subsubsection{Gel Filtration Chromatography}

PHPH-III $(250 \mathrm{mg} / \mathrm{mL})$ was loaded onto a Sephadex G-25 gel filtration column $(2.6 \times 80 \mathrm{~cm}$, GE Healthcare, Uppsala, Sweden), equilibrated with distilled water, and eluted with distilled water at a flow rate of $0.5 \mathrm{~mL} / \mathrm{min}$, each fraction monitored at $220 \mathrm{~nm}$ using an ultraviolet detector, and the freeze-dried fractions was determined using the cellular antioxidant activity assay.

\subsubsection{Reverse-Phase High-Performance Liquid Chromatography (RP-HPLC)}

The active fraction PHPH-III-5 was further loaded onto an XBridge®BEH C18 column $(19 \times 250 \mathrm{~mm}$, Waters, USA) equilibrated with $0.1 \%(v / v)$ TFA and eluted with a linear gradient of acetonitrile $(0-20 \%$ in $30 \mathrm{~min}$ ) containing $0.1 \%$ TFA. The elution rate was $5.0 \mathrm{~mL} / \mathrm{min}$ and each fraction monitored at $220 \mathrm{~nm}$ using the HPLC system and the freeze-dried fractions was determined using the cellular antioxidant activity assay.

\subsubsection{Identification of Peptides by Mass Spectrometry}

The fraction of PHPH-III-5-2 was loaded onto a C18 column eluted with a linear gradient of acetonitrile (0-90\% in $40 \mathrm{~min})$ containing $0.1 \%$ formic acid. Accurate molecular mass and amino acid sequence of PHPH-III-5-2 was determined by a Thermo Scientific $Q$ Exactive mass spectrometer. Spectra were recorded over the mass/charge range 350-1800 ( $\mathrm{m} / \mathrm{z})$.

\subsection{Statistical Analysis}

Data are presented as a means mean \pm standard error of the mean $(n=3$ or 4$)$. Data were analysed using one-way analysis of variance (ANOVA). $p<0.05$ indicated statistical significance.

\section{Conclusions}

In this study, we optimized the enzymatic conditions for trypsin in Pacific herring (C. pallasii) protein, and the optimum hydrolysis conditions were an enzyme concentration of $1394.02 \mathrm{U} / \mathrm{g}$, an extraction time of $7.0 \mathrm{~h}$, a pH of 6.78 , a water/material ratio of $3.51 \mathrm{v} / \mathrm{w}$, and an extraction temperature of $32.06^{\circ} \mathrm{C}$. The purification and characterization of PHPH were reported for the first time in Pacific herring (C. pallasii) protein study, and the peptides Leu-His-Asp-Glu-Leu-Thr (MW = 726.35 Da) and Lys-Glu-Glu-Lys-Phe-Glu (MW $=808.40 \mathrm{Da}$ ) were identified. This research might contribute to a rational application of antioxidant peptides to explore functional foods and drugs to treat diseases associated with oxidative stress. Further research should be performed to investigate the in vivo effects of these peptides.

Author Contributions: Conceptualization, X.W.; Methodology, X.W. and H.Y.; Software, X.W.; Validation, X.W.; Formal Analysis, X.W.; Investigation, X.W.; Resources, X.W.; Data Curation, X.W. and H.Y.; Writing-Original Draft Preparation, X.W.; Writing-Review \& Editing, X.W. and H.Y.; Visualization, X.W.; Supervision, R.X., S.L. and X.C; Project Administration, P.L.; Funding Acquisition, X.W.

Funding: The study was supported by the Key Research and Development Program of Shandong Province (No. 2017YYSP018), STS Project of the Chinese Academy of Sciences (No. 2017T3006), Qingdao Science and Technology Project (No. 17-3-3-21-nsh).

Conflicts of Interest: The authors declare that there is no conflict of interest regarding the publication of this paper. 


\section{References}

1. Sarmadi, B.H.; Ismail, A. Antioxidative peptides from food proteins: A review. Peptides 2010, 31, $1949-1956$. [CrossRef] [PubMed]

2. Borawska, J.; Darewicz, M.; Pliszka, M.; Vegarud, G.E. Antioxidant properties of salmon (Salmo salar L.) protein fraction hydrolysates revealed following their ex vivo digestion and in vitro hydrolysis. J. Sci. Food Agric. 2016, 96, 2764-2772. [CrossRef] [PubMed]

3. Chai, H.-J.; Chan, Y.-L.; Li, T.-L.; Shiau, C.-Y.; Wu, C.-J. Evaluation of lanternfish (Benthosema pterotum) hydrolysates as antioxidants against hydrogen peroxide induced oxidative injury. Food Res. Int. 2013, 54, 1409-1418. [CrossRef]

4. Falowo, A.B.; Fayemi, P.O.; Muchenje, V. Natural antioxidants against lipid-protein oxidative deterioration in meat and meat products: A review. Food Res. Int. 2014, 64, 171-181. [CrossRef] [PubMed]

5. Hsu, K.-C.; Lu, G.-H.; Jao, C.-L. Antioxidative properties of peptides prepared from tuna cooking juice hydrolysates with orientase (Bacillus subtilis). Food Res. Int. 2009, 42, 647-652. [CrossRef]

6. Wolfe, K.L.; Liu, R.H. Cellular antioxidant activity (CAA) assay for assessing antioxidants, foods, and dietary supplements. J. Agric. Food Chem. 2007, 55, 8896-8907. [CrossRef]

7. Frankel, E.N.; Meyer, A.S. The problems of using one-dimensional methods to evaluate multifunctional food and biological antioxidants. J. Sci. Food Agric. 2000, 80, 1925-1941. [CrossRef]

8. Alia, M.; Ramos, S.; Mateos, R.; Granado-Serrano, A.B.; Bravo, L.; Goya, L. Quercetin protects human hepatoma HepG2 against oxidative stress induced by tert-butyl hydroperoxide. Toxicol. Appl. Pharm. 2006, 212, 110-118. [CrossRef] [PubMed]

9. Sarria, B.; Mateos, R.; Gallardo, E.; Ramos, S.; Angeles Martin, M.; Bravo, L.; Goya, L. Nitroderivatives of olive oil phenols protect HepG2 cells against oxidative stress. Food Chem. Toxicol. 2012, 50, 3752-3758. [CrossRef]

10. Yarnpakdee, S.; Benjakul, S.; Kristinsson, H.; Bakken, H. Preventive effect of Nile tilapia hydrolysate against oxidative damage of HepG2 cells and DNA mediated by H2O2 and AAPH. J. Food Sci. Technol. 2015, 52, 6194-6205. [CrossRef]

11. Razali, N.; Mat Junit, S.; Ariffin, A.; Ramli, N.S.; Abdul Aziz, A. Polyphenols from the extract and fraction of T. indica seeds protected HepG2 cells against oxidative stress. BMC Complement. Altern. Med. 2015, 15, 438. [CrossRef] [PubMed]

12. Purcell, M.K.; Bromage, E.S.; Silva, J.; Hansen, J.D.; Badil, S.M.; Woodson, J.C.; Hershberger, P.K. Production and characterization of monoclonal antibodies to IgM of Pacific herring (Clupea pallasii). Fish. Shellfish Immunol. 2012, 33, 552-558. [CrossRef]

13. Hoyle, N.T.; Merritt, J.H. Quality of Fish-Protein Hydrolysates From Herring (Clupea-Harengus). J. Food Sci. 1994, 59, 76-79. [CrossRef]

14. Sathivel, S.; Bechtel, P.J.; Babbitt, J.; Smiley, S.; Crapo, C.; Reppond, K.D.; Prinyawiwatkul, W. Biochemical and functional properties of herring (Clupea harengus), byproduct hydrolysates. J. Food Sci. 2003, 68, 2196-2200. [CrossRef]

15. Alia, M.; Mateos, R.; Ramos, S.; Lecumberri, E.; Bravo, L.; Goya, L. Influence of quercetin and rutin on growth and antioxidant defense system of a human hepatoma cell line (HepG2). Eur. J. Nutr. 2006, 45, 19-28. [CrossRef]

16. Wu, H.; Liu, Z.; Zhao, Y.; Zeng, M. Enzymatic preparation and characterization of iron-chelating peptides from anchovy (Engraulis japonicus) muscle protein. Food Res. Int. 2012, 48, 435-441. [CrossRef]

17. Ren, J.; Zhao, M.; Shi, J.; Wang, J.; Jiang, Y.; Cui, C.; Kakuda, Y.; Xue, S.J. Optimization of antioxidant peptide production from grass carp sarcoplasmic protein using response surface methodology. LWT-Food Sci. Technol. 2008, 41, 1624-1632. [CrossRef]

18. Fang, X.; Xie, N.; Chen, X.; Yu, H.; Chen, J. Optimization of antioxidant hydrolysate production from flying squid muscle protein using response surface methodology. Food Bioprod. Process. 2012, 90, 676-682. [CrossRef]

19. Feng, K.; Chen, W.; Sun, L.; Liu, J.; Zhao, Y.; Li, L.; Wang, Y.; Zhang, W. Optimization extraction, preliminary characterization and antioxidant activity in vitro of polysaccharides from Stachys sieboldii Miq. tubers. Carbohydr. Polym. 2015, 125, 45-52. [CrossRef] 
20. Shao, P.; Jiang, S.T.; Ying, Y.J. Optimization of molecular distillation for recovery of tocopherol from rapeseed oil deodorizer distillate using response surface and artificial neural network models. Food Bioprod. Process. 2007, 85, 85-92. [CrossRef]

21. Batista, I.; Ramos, C.; Coutinho, J.; Bandarra, N.M.; Nunes, M.L. Characterization of protein hydrolysates and lipids obtained from black scabbardfish (Aphanopus carbo) by-products and antioxidative activity of the hydrolysates produced. Process. Biochem. 2010, 45, 18-24. [CrossRef]

22. Wang, X.; Yu, H.; Xing, R.; Chen, X.; Liu, S.; Li, P. Optimization of antioxidative peptides from mackerel (Pneumatophorus japonicus) viscera. Peerj 2018, 6, e4373. [CrossRef]

23. Sarbon, N.M.; Badii, F.; Howell, N.K. Purification and characterization of antioxidative peptides derived from chicken skin gelatin hydrolysate. Food Hydrocoll. 2018, 85, 311-320. [CrossRef]

24. Sabeena Farvin, K.H.; Andersen, L.L.; Otte, J.; Nielsen, H.H.; Jessen, F.; Jacobsen, C. Antioxidant activity of cod (Gadus morhua) protein hydrolysates: Fractionation and characterisation of peptide fractions. Food Chem. 2016, 204, 409-419. [CrossRef]

25. Zhang, Y.; Duan, X.; Zhuang, Y. Purification and characterization of novel antioxidant peptides from enzymatic hydrolysates of tilapia (Oreochromis niloticus) skin gelatin. Peptides 2012, 38, 13-21. [CrossRef]

26. Wang, B.; Li, L.; Chi, C.F.; Ma, J.H.; Luo, H.Y.; Xu, Y.F. Purification and characterisation of a novel antioxidant peptide derived from blue mussel (Mytilus edulis) protein hydrolysate. Food Chem. 2013, 138, 1713-1719. [CrossRef]

27. Ranathunga, S.; Rajapakse, N.; Kim, S.K. Purification and characterization of antioxidative peptide derived from muscle of conger eel (Conger myriaster). Eur. Food Res. Technol. 2006, 222, 310-315. [CrossRef]

28. Yang, X.-R.; Zhang, L.; Ding, D.-G.; Chi, C.-F.; Wang, B.; Huo, J.-C. Preparation, Identification, and Activity Evaluation of Eight Antioxidant Peptides from Protein Hydrolysate of Hairtail (Trichiurus japonicas) Muscle. Mar. Drugs 2019, 17, 23. [CrossRef]

29. Najafian, L.; Babji, A.S. Fractionation and identification of novel antioxidant peptides from fermented fish (pekasam). J. Food Meas. Charact. 2018, 12, 2174-2183. [CrossRef]

30. Suetsuna, K.; Ukeda, H.; Ochi, H. Isolation and characterization of free radical scavenging activities peptides derived from casein. J. Nutr. Biochem. 2000, 11, 128-131. [CrossRef]

31. Aleman, A.; Gimenez, B.; Perez-Santin, E.; Gomez-Guillen, M.C.; Montero, P. Contribution of Leu and Hyp residues to antioxidant and ACE-inhibitory activities of peptide sequences isolated from squid gelatin hydrolysate. Food Chem. 2011, 125, 334-341. [CrossRef]

32. Umayaparvathi, S.; Arumugam, M.; Meenakshi, S.; Dräger, G.; Kirschning, A.; Balasubramanian, T. Purification and Characterization of Antioxidant Peptides from Oyster (Saccostrea cucullata) Hydrolysate and the Anticancer Activity of Hydrolysate on Human Colon Cancer Cell Lines. Int. J. Pept Res. Ther. 2013, 20, 231-243. [CrossRef]

33. Kim, S.Y.; Je, J.Y.; Kim, S.K. Purification and characterization of antioxidant peptide from hoki (Johnius belengerii) frame protein by gastrointestinal digestion. J. Nutr. Biochem. 2007, 18, 31-38. [CrossRef]

34. Rajapakse, N.; Mendis, E.; Byun, H.G.; Kim, S.K. Purification and in vitro antioxidative effects of giant squid muscle peptides on free radical-mediated oxidative systems. J. Nutr. Biochem. 2005, 16, 562-569. [CrossRef]

35. Chi, C.F.; Hu, F.Y.; Wang, B.; Li, Z.R.; Luo, H.Y. Influence of Amino Acid Compositions and Peptide Profiles on Antioxidant Capacities of Two Protein Hydrolysates from Skipjack Tuna (Katsuwonus pelamis) Dark Muscle. Mar. Drugs 2015, 13, 2580-2601. [CrossRef]

36. Zhou, D.-Y.; Tang, Y.; Zhu, B.-W.; Qin, L.; Li, D.-M.; Yang, J.-F.; Lei, K.; Murata, Y. Antioxidant activity of hydrolysates obtained from scallop (Patinopecten yessoensis) and abalone (Haliotis discus hannai Ino) muscle. Food Chem. 2012, 132, 815-822. [CrossRef]

37. Sampath Kumar, N.S.; Nazeer, R.A.; Jaiganesh, R. Purification and identification of antioxidant peptides from the skin protein hydrolysate of two marine fishes, horse mackerel (Magalaspis cordyla) and croaker (Otolithes ruber). Amino Acids 2012, 42, 1641-1649. [CrossRef]

38. Uysal, S.; Cvetanovic, A.; Zengin, G.; Durovic, S.; Aktumsek, A. Optimization of the extraction process of antioxidants from loquat leaves using response surface methodology. J. Food Process. Pres. 2017, 41. [CrossRef]

39. Bezerra, M.A.; Santelli, R.E.; Oliveira, E.P.; Villar, L.S.; Escaleira, L.A. Response surface methodology (RSM) as a tool for optimization in analytical chemistry. Talanta 2008, 76, 965-977. [CrossRef] 
40. Luo, F.L.; Xing, R.E.; Wang, X.Q.; Peng, Q.C.; Li, P.C. Proximate composition, amino acid and fatty acid profiles of marine snail Rapana venosa meat, visceral mass and operculum. J. Sci. Food Agric. 2017, 97, 5361-5368. [CrossRef]

41. Kong, K.W.; Mat-Junit, S.; Aminudin, N.; Hassan, F.A.; Ismail, A.; Aziz, A.A. Protective effects of the extracts of Barringtonia racemosa shoots against oxidative damage in HepG2 cells. Peerj 2016, 4. [CrossRef]

42. Smeriglio, A.; Denaro, M.; Barreca, D.; Calderaro, A.; Bisignano, C.; Ginestra, G.; Bellocco, E.; Trombetta, D. In Vitro Evaluation of the Antioxidant, Cytoprotective, and Antimicrobial Properties of Essential Oil from Pistacia vera L. Variety Bronte Hull. Int. J. Mol. Sci. 2017, 18, 1212. [CrossRef]

43. Blois, M.S. Antioxidant Determinations By The Use Of A Stable Free Radical. Nature 1958, 181, 1199-1200. [CrossRef]

44. Luo, F.; Xing, R.; Wang, X.; Yang, H.; Li, P. Antioxidant activities of Rapana venosa meat and visceral mass during simulated gastrointestinal digestion and their membrane ultrafiltration fractions. Int. J. Food Sci. Technol. 2018, 53, 395-403. [CrossRef]

Sample Availability: Samples of the compounds Pacific herring peptides are available from the authors.

(C) 2019 by the authors. Licensee MDPI, Basel, Switzerland. This article is an open access article distributed under the terms and conditions of the Creative Commons Attribution (CC BY) license (http://creativecommons.org/licenses/by/4.0/). 